\title{
1. How do you become entrepreneurial in one week?
}

\author{
Lise Aaboen, Hans Landström and Roger \\ Sørheim
}

\section{SETTING THE SCENE}

Entrepreneurship has become a catchword in academia. Education in entrepreneurship has expanded from a business school offering to an education offered to students within many other disciplines. Moreover, entrepreneurship scholars are extensively involved with course development and pedagogical initiatives, and new ways of teaching have been developed featuring new methods and overarching ideas about what an entrepreneurship education should entail (Fayolle, 2013; Katz, 2003; Neck and Corbett, 2018; Vesper and Gartner, 1997). Thus, universities offer a broad range of entrepreneurship education programmes, courses, cross-disciplinary activities, co-curricular activities and students' clubs for entrepreneurship with business plan competitions, internships, grants and venture creation activities (Levie, 2014; Morris et al., 2014). The pedagogy of entrepreneurship education and course curricula have evolved significantly. Now, entrepreneurship activities include everything from traditional case solving, simulations, games and student enterprises which only exist during the course, to more advanced pedagogical approaches, such as internships, consultant businesses and new technology-based venture creation. Typically, entrepreneurship education activities are categorised into (a) education which intends to wake dormant entrepreneurs; (b) stimulation activities for supporting a process from idea to business plan; and (c) incubation activities to ensure that start-ups can survive independently (Jansen et al., 2015).

In this book, we will focus on one such activity: activities aiming to make students more entrepreneurial through week-long courses, camps and/or summer schools. A brief explanation of a start-up weekend is 'an event for young entrepreneurs (and those who want to be one) to work creatively in a low-risk, high-energy atmosphere and develop ideas into small businesses' (Hiss, 2018: 64). We have witnessed first-hand that such activities have 
increased significantly in practice over the last five years. An early description of such initiatives involves the three camps described by Bager (2011): a student camp aimed at developing student ideas, a student camp aimed at company innovation, and a student camp aimed at university commercialisation. Bager's (2011) article demonstrates three shortcomings typical of articles describing short initiatives. First, such articles focus on describing the camps. Second, the outcomes of the camps are unclear. There is no information regarding what 'very positive' refers to. Even though it is assumed that students have increased their understanding and self-efficacy, this is not explicitly assessed. Third, Bager (2011) shows that, even if the three camps have divergent aims, there are still common denominators in short initiatives. Typically, students work in teams to solve a challenge in a specific location with facilitators.

This book overcomes the shortcomings in the literature exemplified by Bager (2011), and we will collect examples of such short initiatives from various countries and contexts. The ultimate aims of the book are: (1) to provide examples of short initiatives from European research-based universities which show what activities they use, how they have developed and how they seek to contribute to the entrepreneurial activities at their universities; and (2) to initiate a discussion which will improve the quality of one-week initiatives and advance the research frontier of such initiatives beyond a pre-test/post-test of entrepreneurial mindsets and intentions. In the entrepreneurship education literature, authors sometimes differentiate between 'entrepreneurship' education and 'enterprise' education. For instance, Rae et al. (2012: 382) use the definition 'enterprise' when they describe 'students learning to use the skills, knowledge and personal attributes needed to apply creative ideas and innovations to practical situations' while 'entrepreneurship' is used to describe 'the study of enterprise and entrepreneurs, including the practical and academic knowledge, skills and techniques used in being an entrepreneur'. However, the words tend to be used interchangeably (Hannon, 2005), and following this trend we primarily use the term 'entrepreneurship' in the present book.

The book has been developed in the following way. An invitation to contribute chapters to a book about short entrepreneurship education initiatives was sent out in the early spring of 2018. Based on the extended abstracts submitted, chapters were selected. The selection process took into consideration the geographical context and content of the initiatives as well as the inclusion of different types of initiatives in order to provide a European view of short entrepreneurship education initiatives. Once the book proposal was approved, the authors of the selected extended abstracts were invited to submit full paper drafts of their chapters. A first round of reviews was provided by the editors. After the submission of the second drafts of the 
chapters, the chapter authors performed a review of each other's chapters so that each chapter received a review from the authors of two other chapters. Furthermore, the chapter authors were invited to a seminar in Trondheim where they acted as discussants on each other's papers. This seminar provided valuable comments for the chapters and a common understanding of what the book was about. The third drafts of the chapters were reviewed by the editors, and the fourth draft was the final draft for most chapters while a few received additional minor comments.

\section{CONTENT OF THE BOOK}

The book consists of three parts: Part I: Skills, competencies and awareness among students; Part II: Start-ups and entrepreneurs from the university; and Part III: Entrepreneurial citizens. Part I includes initiatives which focus on instilling an entrepreneurial mindset in students or inspiring the students to entrepreneurial thinking through teamwork. The result is often a pitch or presentation about how the students solved a challenge. In initiatives in Part II, the intended result is to contribute to the 'third mission' of the university by preparing students for careers as entrepreneurs. Part III describes initiatives which are part of collaborations between universities. Such initiatives are often influenced by the collaborations they are based on and often have a regional or societal goal for their activities. Below, we introduce the parts and chapters of the book.

\section{Part I: Skills, Competencies and Awareness among Students}

The Workshop for Innovation and Entrepreneurship (WOFIE) was a four-day workshop designed to provide students with a tangible understanding of innovation and entrepreneurship at Aalborg University, Denmark. It was targeted towards second-year master's students from all disciplines at three campus locations, and every year approximately 300 students passed the course. The workshop included a large group of facilitators and was based on a WOFIE guide map focusing on the dimensions of unique, verify, business and convince. The chapter provides a description of how the workshop developed between 2008 and 2017. In particular, the chapter emphasises the informal aspects of organising entrepreneurship education initiatives before, during and after WOFIE was offered.

The Innovation Camp is a mandatory three-day course introducing nursing students to the need for innovations in healthcare at the Norwegian University of Science and Technology, Norway. In order to meet the new national learning objectives for nursing students, the Unit for Nursing collaborates with an organisation for youth entrepreneurship, the municipality, 
the hospital and a national centre for entrepreneurship education. During the course, the students attend lectures and work in teams to develop innovative ideas which are presented to a jury at the end of the course. In particular, the chapter focuses on the particularities of the healthcare context.

SEMIS is a mandatory four-day course for instilling entrepreneurial competencies in the first-year master's students at TBS Business School, France. The teamwork, which follows a design thinking methodology, is based on challenges in the areas of boldness, excellence, openness and responsibility. The course culminates in a pitch contest. In particular, the chapter focuses on the use of internal university challenges for short entrepreneurship education and the opportunity to build a learning community by inviting university professors from all disciplines to join the initiative as coaches.

The Leeds International Summer School (LISS) is an international summer programme at the University of Leeds in the UK. The programme use lectures, teamwork, daily reflective journals and field trips to help students understand the skills, attributes and abilities of entrepreneurs as well as how entrepreneurship can be used as a vehicle to bring about social change. In particular, the chapter focuses on how the initiative becomes an environment in which faculty can experiment with new ways of teaching and $\mathrm{PhD}$ students can get teaching experience.

\section{Part II: Start-ups and Entrepreneurs from the University}

Sommarmatchen is a summer programme for verifying research results and moving projects closer to market in order to create an awareness of entrepreneurship as a career path at Linköping University, Sweden. During the programme, students are matched with a research idea and after an initial week of crash courses in such activities as cold calling, the students work with the idea during the summer and deliver a report and a presentation. In particular, the chapter focuses on the planning and organisation needed in order to accomplish successful matches between students, researchers and research.

Entrepreneurship for Research Professionals is an elective course for $\mathrm{PhD}$ students from all disciplines at the University of Turku, Finland, aimed at widening their career perspectives from academia to business life. The course demonstrates the entrepreneurial process and consists of pre-readings, a ten-hour learning camp, a learning diary kept for two weeks, and a wrap-up session. In particular, the chapter focuses on the importance of teamwork, entrepreneurial action and time scarcity for this group of students.

VentureLab Weekend is a three-day extracurricular learning event for bachelor's, master's and $\mathrm{PhD}$ students from all disciplines. The event aims at the development of entrepreneurial competencies and business ideas into well-developed business models and investor pitches at the University 
of Groningen, the Netherlands. During the event, workshop activities are combined with working with peers, and the numerous activities include feedback, working and coaching. The organisers work extensively with national and international partners. In particular, the chapter elaborates on the event's participant-centred approach.

PIE 17-088 is an extracurricular initiative at the University of Malaga in Spain which trains students in competencies related to entrepreneurship as a differentiating factor in being more competitive in the labour market. In the initiative, students choose between a hackathon, team building, practical cases with entrepreneurs and role playing. The organisers then determine which training activities seem most attractive and effective. In particular, the chapter emphasises the importance of experimentation and stakeholder involvement during the development of entrepreneurship initiatives in higher education.

\section{Part III: Entrepreneurial Citizens}

Pursuing Entrepreneurship is an extracurricular course at Aarhus University in Denmark where students learn how to pitch and apply the Lean Startup methodology tools and understand that ideas develop in interactions between people. Three institutions - Aarhus University, VIA University College and Business Academy Aarhus - have collaboratively committed to the goals of 7000 students receiving extracurricular entrepreneurship education, 2500 students signing an incubator contract and 350 students starting an officially registered venture. Pursuing Entrepreneurship is part of the plan to reach these goals. During the two-week course, participants develop their ideas through workshops and videos which the participants receive through text messages. In particular, the chapter focuses on the blended learning resulting from the use of both workshops and videos and how the tracking of the videos enables the organisers to follow the engagement of the students during different parts of the course.

5UCV-E2 is an extracurricular course which coaches students in entrepreneurship and nurtures their adaptive capabilities at five universities simultaneously in the region of Valencia, Spain. The collaboration of the five universities is coordinated with the help of Dirección General de Economía, Emprendimiento y Cooperativismo of the Valencian regional government and the Santander International Entrepreneurship Centre to help the universities in carrying out and designing the programme. During the programme, students work in teams facilitated by student tutors and local entrepreneurs following worksheets during seven sessions. In particular, the chapter focuses on the activities which have been carried out to foster collaboration 
between the participating organisations. 5UCV-E2 is one of seven extracurricular activities carried out by the same consortium.

ComoNExT iStart Academy guided the participants through the lean start-up process using lectures, teamwork and mentoring for five days in Lomazzo, Italy. The extracurricular course was part of an Erasmus+ Key Action 2 (KA2) strategic partnership project. The project consortium consists of universities, incubators, research centres and business angels from Turkey, the United Kingdom, Greece, Portugal, Belgium and Italy and aims to contribute to growth, jobs, social equality and inclusion through a lean-training, innovative, multidisciplinary digital entrepreneurship platform. In particular, the chapter focuses on how the network among the actors in the consortium enabled the ComoNExT iStart Academy.

\section{LESSONS LEARNED ABOUT SHORT ENTREPRENEURSHIP EDUCATION INITIATIVES}

All short entrepreneurship education initiatives covered in the book are based on a process the students go through during the initiative to experience the activities and reach the intended result at the end of the programme. The initiatives detailed in Part I all focus on idea development leading to a presentation at the end, while Part II provides examples of initiatives in which the focus is on a somewhat later stage of venture development. In some of the initiatives, the process itself is designed to simulate the entrepreneurial process of finding a business opportunity using elements from, for instance, design thinking. In other words, being guided through the process and learning, for instance, how to pitch are important concrete goals of the initiative. At the student level, the initiatives also present goals such as developing and nurturing capabilities, developing competencies, creating awareness, introducing transformative learning and providing an understanding of entrepreneurship, which are more difficult to evaluate (Table 1.1). Most of the initiatives also have goals at the university, regional and national levels which they want to reach or contribute to. These goals have included meeting national learning objectives of providing entrepreneurship to all students or a certain number of students and creating jobs and growth.

The measured results presented in the chapters are mostly quotes from surveys and interviews regarding student satisfaction and perceived learning. Given the short time frame of the initiatives, it may be difficult to detect new capabilities, competencies and transformative learning even though an initiative may have provided a student's first inspiration in that direction. Similarly, in terms of the goals regarding jobs and growth, it may be that the initiative, together with other efforts, makes a change, but it will be difficult 


\section{Table 1.1 Target students and goals}

\begin{tabular}{|c|c|c|}
\hline & Audience/Students & Goals \\
\hline $\begin{array}{l}\text { WOFIE, } \\
\text { Aalborg University }\end{array}$ & $\begin{array}{l}\text { Master's students from all } \\
\text { disciplines }\end{array}$ & $\begin{array}{l}\text { Tangible understanding of innovation and } \\
\text { entrepreneurship }\end{array}$ \\
\hline $\begin{array}{l}\text { The Innovation Camp, } \\
\text { Norwegian University of } \\
\text { Science and Technology }\end{array}$ & $\begin{array}{l}\text { Third-year nursing } \\
\text { students }\end{array}$ & $\begin{array}{l}\text { Fulfil new national learning objectives; } \\
\text { Introduce the need for innovation in healthcare }\end{array}$ \\
\hline $\begin{array}{l}\text { SEMIS, } \\
\text { Toulouse Business School }\end{array}$ & $\begin{array}{l}\text { All first-year master's } \\
\text { students }\end{array}$ & Instil entrepreneurial competencies \\
\hline $\begin{array}{l}\text { LISS, } \\
\text { University of Leeds }\end{array}$ & $\begin{array}{l}\text { International } \\
\text { undergraduate } \\
\text { students with no } \\
\text { previous knowledge of } \\
\text { entrepreneurship }\end{array}$ & $\begin{array}{l}\text { Understand the skills, attributes and abilities of } \\
\text { entrepreneurs as well as how entrepreneurship } \\
\text { can be used as a vehicle to bring about social } \\
\text { change }\end{array}$ \\
\hline $\begin{array}{l}\text { Sommarmatchen, } \\
\text { Linköping University }\end{array}$ & $\begin{array}{l}\text { Students from all } \\
\text { disciplines; Previously, } \\
\text { primarily engineering and } \\
\text { economics }\end{array}$ & $\begin{array}{l}\text { Awareness of alternative careers; Moving } \\
\text { research results one step closer to the market }\end{array}$ \\
\hline $\begin{array}{l}\text { Entrepreneurship for } \\
\text { Research Professionals, } \\
\text { University of Turku }\end{array}$ & $\begin{array}{l}\mathrm{PhD} \text { students from all } \\
\text { disciplines }\end{array}$ & $\begin{array}{l}\text { Widen students' career perspectives from } \\
\text { academia to business life }\end{array}$ \\
\hline $\begin{array}{l}\text { VentureLab Weekend, } \\
\text { University of Groningen }\end{array}$ & $\begin{array}{l}\text { Bachelor's, master's and } \\
\text { PhD students from all } \\
\text { disciplines }\end{array}$ & $\begin{array}{l}\text { Development of entrepreneurial competencies } \\
\text { and business ideas into well-developed } \\
\text { business models and investor pitches }\end{array}$ \\
\hline $\begin{array}{l}\text { PIE 17-088, } \\
\text { University of Malaga }\end{array}$ & $\begin{array}{l}\text { Students from all } \\
\text { disciplines }\end{array}$ & $\begin{array}{l}\text { Training in competencies related to } \\
\text { entrepreneurship as a differentiating factor in } \\
\text { being more competitive in the labour market }\end{array}$ \\
\hline $\begin{array}{l}\text { Pursuing Entrepreneurship, } \\
\text { Aarhus University }\end{array}$ & $\begin{array}{l}\text { Students from all } \\
\text { disciplines }\end{array}$ & $\begin{array}{l}\text { Learn how to pitch, apply Lean Startup tools } \\
\text { and develop an understanding that ideas } \\
\text { develop in interactions between people }\end{array}$ \\
\hline $\begin{array}{l}\text { 5UCV-E2, } \\
\text { University of Valencia }\end{array}$ & $\begin{array}{l}\text { Students from all } \\
\text { disciplines for the } \\
\text { teams and students } \\
\text { with entrepreneurship } \\
\text { backgrounds as tutors }\end{array}$ & Develop and nurture adaptive capabilities \\
\hline $\begin{array}{l}\text { ComoNExT iStart } \\
\text { Academy, Catholic } \\
\text { University of the Sacred } \\
\text { Heart }\end{array}$ & $\begin{array}{l}\text { Students from all } \\
\text { disciplines }\end{array}$ & $\begin{array}{l}\text { Contribute to growth, jobs, social equality and } \\
\text { inclusion through a lean-training, innovative, } \\
\text { multidisciplinary digital entrepreneurship } \\
\text { platform }\end{array}$ \\
\hline
\end{tabular}


to isolate the effects of the particular week of training. Even if a former participant starts a business later, it will be difficult to know that it was because of a particular initiative. However, providing an initial awareness of entrepreneurship or guiding students through a useful process may be valuable, more attainable within the timeframe and easier to measure. We found it interesting to notice that these initiatives are sometimes used to meet new national learning objectives of introducing all students to entrepreneurship. The format provides the opportunity to experiment with the content, but there is also a risk that entrepreneurship may be perceived as an add-on rather than an integrated part of curricula. We also noted that at least two of the initiatives used the course to try out new ways of teaching and to provide teaching training to new faculty and faculty from disciplines other than entrepreneurship. In this way, an initiative may become a way to improve entrepreneurship teaching in other courses as well.

The short entrepreneurship education initiatives tended to be extracurricular except for the initiatives in Part I, all but one of which were mandatory. A common denominator for the mandatory initiatives was that they all wanted to ensure that all students become equipped with the tools needed to develop an opportunity. The initiatives in Part III are based on consortia of universities and other actors. The activities which take place in order to make the collaboration work and to enable the initiatives are important for these initiatives. However, the other initiatives also mention external actors, for example, an organisation for youth entrepreneurship as well as local entrepreneurs and technology transfer offices. It also seems important that an organisation sponsoring the initiative is well connected in the university. Some initiatives are organised by centres which are semi-independent from the regular faculties (Table 1.2). This enables them to connect with all parts of the university without being dependent on as many structures. However, it also makes it particularly important for them to anchor the initiative in the organisation so that they are able to access students and resources. For instance, it is mentioned by one initiative that the local teaching environments sometimes 'forgot' to communicate the initiative or planned study tours, which prevented their students from participating because the local teaching environments did not see the point of innovation and entrepreneurship for their students. Another example regarding organisational anchoring is that the organisers of some of the initiatives previously held important positions in entrepreneurship-related activities and thus had the legitimacy necessary to organise the initiative and access all students as well as important decision-makers in the university.

The pedagogical approaches used were mostly experiential learning in which the students worked on a project in groups with mentoring and 
Table 1.2 Organisation of the initiatives

\begin{tabular}{|c|c|}
\hline & Organisation \\
\hline $\begin{array}{l}\text { WOFIE, } \\
\text { Aalborg University }\end{array}$ & $\begin{array}{l}\text { Guide map, script and video links to ensure that the event was run consistently } \\
\text { in all locations; Supporting Entrepreneurship at Aalborg was the formal } \\
\text { coordinator; Informal network which has organised similar initiatives since } \\
\text { WOFIE }\end{array}$ \\
\hline $\begin{array}{l}\text { The Innovation Camp, } \\
\text { Norwegian University of } \\
\text { Science and Technology }\end{array}$ & $\begin{array}{l}\text { Organised by the nursing faculty in collaboration with an organisation for } \\
\text { youth entrepreneurship, the municipality, the university hospital, a centre for } \\
\text { entrepreneurship education and a student organisation for entrepreneurship }\end{array}$ \\
\hline $\begin{array}{l}\text { SEMIS, } \\
\text { Toulouse Business } \\
\text { School }\end{array}$ & $\begin{array}{l}\text { Organised by two professors who previously held positions in the university } \\
\text { entrepreneurship system }\end{array}$ \\
\hline $\begin{array}{l}\text { LISS, } \\
\text { University of Leeds }\end{array}$ & Organised by the Centre for Enterprise and Entrepreneurship Studies \\
\hline $\begin{array}{l}\text { Sommarmatchen, } \\
\text { Linköping University }\end{array}$ & Organised by the Technology Transfer Office \\
\hline $\begin{array}{l}\text { Entrepreneurship for } \\
\text { Research Professionals, } \\
\text { University of Turku }\end{array}$ & Organised by the Entrepreneurship Unit on behalf of the graduate school \\
\hline $\begin{array}{l}\text { VentureLab Weekend, } \\
\text { University of Groningen }\end{array}$ & $\begin{array}{l}\text { Organised by the University of Groningen Centre of Entrepreneurship as part of } \\
\text { their entrepreneurship funnel; Many international partners and collaborations }\end{array}$ \\
\hline $\begin{array}{l}\text { PIE } 17-088, \\
\text { University of Malaga }\end{array}$ & $\begin{array}{l}\text { Organised as a project at the University of Malaga; External collaborators for } \\
\text { some of the activities }\end{array}$ \\
\hline $\begin{array}{l}\text { Pursuing } \\
\text { Entrepreneurship, } \\
\text { Aarhus University }\end{array}$ & $\begin{array}{l}\text { Organised by the Aarhus University Incubator; Collaboration between three } \\
\text { Danish universities; Funded by the region and the European Social Fund }\end{array}$ \\
\hline $\begin{array}{l}\text { 5UCV-E2, } \\
\text { University of Valencia }\end{array}$ & $\begin{array}{l}\text { Organised by a collaboration between five Valencian universities, the regional } \\
\text { government and the Santander International Entrepreneurship Centre }\end{array}$ \\
\hline $\begin{array}{l}\text { ComoNExT iStart } \\
\text { Academy, Catholic } \\
\text { University of the Sacred } \\
\text { Heart }\end{array}$ & $\begin{array}{l}\text { Part of an Erasmus+ KA2 strategic partnership project; The project consortium } \\
\text { consists of universities, incubators, research centres and business angels from } \\
\text { Turkey, the UK, Greece, Portugal, Belgium and Italy }\end{array}$ \\
\hline
\end{tabular}

attended lectures to learn the tools they needed during their project (Table 1.3). There were also excursions to local entrepreneurs, reflection diaries and short movies on SMS to complement the experiential learning. There are rather traditional pedagogical approaches used in these initiatives. However, we noticed some attempts to think differently, such as the use of the movies to measure the engagement of the students and the effort to include the students in designing the entrepreneurship education. We find it interesting that the pedagogical approaches are so similar in the different initiatives, given that they are designed for different students, for different goals and in 
different contexts. There seems to be an emphasis on teaching the students how to use tools such as design thinking or lean start-up rather than on specific content. Furthermore, the initiatives do not seem to be connected to the other courses at the institutions of which they are part. For the extracurricular courses, it may be natural that they are more connected to the other extracurricular activities of the university. For the initiatives which are part of the curriculum or even mandatory it could perhaps be possible to connect to other courses and thereby contextualise the content of the initiative and/or prolong the learning of entrepreneurship. Another interesting observation is that the majority of the activities seem to take place at the university and in interaction with other students and faculty. Except for talking with potential users as part of the design thinking and lean start-up processes, very little of the experiential learning seems to be connected to the 'real world'. It seems to involve more 'classroom' exercises preparing students to carry out similar activities in the 'real world' later. Initiatives in which students work on developing research ideas for the commercial market seem to be an exception.

Table 1.3 Pedagogical approach in the initiatives

\begin{tabular}{|c|c|c|c|}
\hline & Pedagogical approach & Extracurricular/curricular & $\begin{array}{l}\text { Contact with external } \\
\text { actors }\end{array}$ \\
\hline $\begin{array}{l}\text { WOFIE, } \\
\text { Aalborg University }\end{array}$ & $\begin{array}{l}\text { Changed from } \\
\text { a creativity-based } \\
\text { approach to } \\
\text { a business-based } \\
\text { approach; Group } \\
\text { work using design } \\
\text { thinking-based } \\
\text { framework }\end{array}$ & Elective course & $\begin{array}{l}\text { Judges and expert } \\
\text { panels }\end{array}$ \\
\hline $\begin{array}{l}\text { The Innovation Camp, } \\
\text { Norwegian University } \\
\text { of Science and } \\
\text { Technology }\end{array}$ & $\begin{array}{l}\text { Group work to develop } \\
\text { an idea for solving } \\
\text { a challenge following } \\
\text { the framework provided } \\
\text { by the organisation for } \\
\text { youth entrepreneurship }\end{array}$ & Curricular and mandatory & $\begin{array}{l}\text { The stakeholders } \\
\text { providing the } \\
\text { challenges }\end{array}$ \\
\hline $\begin{array}{l}\text { SEMIS, } \\
\text { Toulouse Business } \\
\text { School }\end{array}$ & $\begin{array}{l}\text { Group work to develop } \\
\text { a solution to a challenge } \\
\text { provided by the } \\
\text { university based on } \\
\text { design thinking }\end{array}$ & Curricular and mandatory & $\begin{array}{l}\text { Experts and potential } \\
\text { users }\end{array}$ \\
\hline
\end{tabular}




\begin{tabular}{|c|c|c|c|}
\hline & Pedagogical approach & Extracurricular/curricular & $\begin{array}{l}\text { Contact with external } \\
\text { actors }\end{array}$ \\
\hline $\begin{array}{l}\text { LISS, } \\
\text { University of Leeds }\end{array}$ & $\begin{array}{l}\text { Lectures, teamwork, } \\
\text { daily reflective journals } \\
\text { and field trips }\end{array}$ & Extracurricular, summer & $\begin{array}{l}\text { Local entrepreneurs } \\
\text { and organisations }\end{array}$ \\
\hline $\begin{array}{l}\text { Sommarmatchen, } \\
\text { Linköping University }\end{array}$ & $\begin{array}{l}\text { NABC framework; } \\
\text { Crash course, } \\
\text { independent work and } \\
\text { presentation }\end{array}$ & Extracurricular, summer & Researchers \\
\hline $\begin{array}{l}\text { Entrepreneurship for } \\
\text { Research Professionals, } \\
\text { University of Turku }\end{array}$ & $\begin{array}{l}\text { Pre-readings, ten-hour } \\
\text { learning camp, learning } \\
\text { diary for two weeks, } \\
\text { and wrap-up session; } \\
\text { Develop idea based on } \\
\text { interest; Lean start-up; } \\
\text { Motorola reflection tool }\end{array}$ & Elective course & Potential users \\
\hline $\begin{array}{l}\text { VentureLab Weekend, } \\
\text { University of Groningen }\end{array}$ & $\begin{array}{l}\text { Workshop moments are } \\
\text { combined with working } \\
\text { with peers moments, } \\
\text { and there are numerous } \\
\text { active moments, such as } \\
\text { feedback, working and } \\
\text { coaching }\end{array}$ & Extracurricular & $\begin{array}{l}\text { Coaches from the local } \\
\text { ecosystem, panels and } \\
\text { potential users }\end{array}$ \\
\hline $\begin{array}{l}\text { PIE 17-088, } \\
\text { University of Malaga }\end{array}$ & $\begin{array}{l}\text { The students choose } \\
\text { between a hackathon, } \\
\text { team building, } \\
\text { practical cases with an } \\
\text { entrepreneur and role } \\
\text { playing }\end{array}$ & Extracurricular & $\begin{array}{l}\text { Some activities } \\
\text { take place in the } \\
\text { entrepreneurs fair }\end{array}$ \\
\hline $\begin{array}{l}\text { Pursuing } \\
\text { Entrepreneurship, } \\
\text { Aarhus University }\end{array}$ & $\begin{array}{l}\text { Develop idea through } \\
\text { kick-off, development } \\
\text { with videos using the } \\
\text { NABC framework } \\
\text { and a workshop for } \\
\text { reflection }\end{array}$ & Extracurricular & $\begin{array}{l}\text { Test the idea on } \\
\text { potential customers }\end{array}$ \\
\hline $\begin{array}{l}\text { 5UCV-E2, } \\
\text { University of Valencia }\end{array}$ & $\begin{array}{l}\text { Teamwork using } \\
\text { worksheets together with } \\
\text { student tutors and local } \\
\text { entrepreneurs to develop } \\
\text { a business model }\end{array}$ & Extracurricular & Local entrepreneurs \\
\hline $\begin{array}{l}\text { ComoNExT iStart } \\
\text { Academy, Catholic } \\
\text { University of the Sacred } \\
\text { Heart }\end{array}$ & $\begin{array}{l}\text { Lectures, teamwork } \\
\text { and mentoring; Virtual } \\
\text { learning environment } \\
\text { (VLE); Lean start-up }\end{array}$ & Extracurricular & $\begin{array}{l}\text { Mentors, tutors, } \\
\text { experts and potential } \\
\text { users }\end{array}$ \\
\hline
\end{tabular}




\section{CHANGING THE SCENE}

The development of short entrepreneurship education initiatives so far seems to be fuelled by external pressure to provide entrepreneurship to more or all students. The traditional structure of universities does not seem entirely suitable for these initiatives. The development of the initiatives has, therefore, often been conducted by freestanding units with entrepreneurship competency or faculty together with external collaboration partners with the same competency. Even though the use of freestanding units, ad hoc teachers and practitioners as facilitators has enabled the introduction of these initiatives, it also hampers the initiatives during their further development as it makes the initiatives loosely coupled with the competency and management structures of the university. The lack of embeddedness in the university structure prevents the initiatives from benefiting from the continuous pedagogical development which faculty conduct in regular study programmes. Simultaneously, the traditional programmes are not benefiting from the learning activities used in the initiative.

The time span provides less time for reflection, so the experiential learning is rather limited compared with a full course or a study programme in entrepreneurship. It is possible, therefore, to discuss whether entrepreneurship education has actually been provided to the students of these short initiatives. It is, of course, connected to the goals, but it may be wise not to set goals beyond providing awareness of entrepreneurship. Furthermore, student satisfaction provides leverage in negotiations, and the offering of tools which are popular and common provides legitimacy to the initiative. However, in isolation, the short entrepreneurship education initiatives currently in use run the risk of becoming simply fun events during education, also known as intellectually comfortable 'McEducation' (Hytti, 2018).

For the future development of short entrepreneurship education initiatives, we suggest increased contextualisation so that initiatives are relevant for the students who are attending instead of one-size-fits-all add-ons. In other words, we suggest that initiatives could be different depending on the students they are targeting and the context in which they are developed. One step in accomplishing this may be that more initiatives use the short initiatives as test beds for new ways of teaching and for educating faculty in entrepreneurship education. Furthermore, we suggest that opportunities be provided for continuing to work on the ideas developed either as part of thesis work, in courses or in extracurricular initiatives. Moreover, we suggest that the initiatives could become integrated parts of disciplinary courses. In this way, the initiatives will become less standardised and homogeneous over time as well as more embedded in the university and the education provided by the university. 


\section{ACKNOWLEDGEMENT}

The authors would like to acknowledge the financial support provided by Engage - Centre for Engaged Education through Entrepreneurship.

\section{REFERENCES}

Bager, T. (2011), 'The camp model for entrepreneurship teaching', International Entrepreneurship Management Journal, 7, 279-96.

Fayolle, A. (2013), 'Personal views on the future of entrepreneurship education', Entrepreneurship \& Regional Development, 25 (7-8), 692-701.

Hannon, P.D. (2005), 'Philosophies of enterprise and entrepreneurship education and challenges for higher education in the UK', Entrepreneurship and Innovation, 6 (2), 105-14.

Hiss, F. (2018), 'Talk, time, and creativity: Developing ideas and identities during a start-up weekend', Language \& Communication, 60, 64-79.

Hytti, U. (2018), 'Critical entrepreneurship education: A form of resistance to McEducation', in Karin Berglund and Karen Verduijn (eds), Revitalizing Entrepreneurship Education. Adopting a Critical Approach in the Classroom, Abingdon: Routledge, pp. 228-40.

Jansen, S., T. van de Zande, S. Brinkkemper, E. Stam and V. Varma (2015), 'How education, stimulation, and incubation encourage entrepreneurship: Observations from MIT, IIIT, and Utrecht University', The International Journal of Management Education, 13, 170-81.

Katz, J.A. (2003), 'The chronology and intellectual trajectory of American entrepreneurship education', Journal of Business Venturing, 18 (2), 283-300.

Levie, J. (2014), 'The university is the classroom: Teaching and learning technology commercialization at a technological university', Journal of Technology Transfer, 39 (5), 793-808.

Morris, N.M., D.F. Kuratko and C.G. Pryor (2014), 'Building blocks for the development of university-wide entrepreneurship', Entrepreneurship Research Journal, 4 (1), 45-68.

Neck, H.M. and A.C. Corbett (2018), 'The scholarship of teaching and learning entrepreneurship', Entrepreneurship Education and Pedagogy, 1 (1), 8-41.

Rae, D., L. Martin, V. Antcliff and P. Hannon (2012), 'Enterprise and entrepreneurship in English higher education: 2010 and beyond', Journal of Small Business and Enterprise Development, 19 (3), 380-401.

Vesper, K.H. and W.B. Gartner (1997), 'Measuring progress in entrepreneurship education', Journal of Business Venturing, 12 (5), 403-21. 